\title{
The effect of education supervisor assistants' organizational justice perceptions on their level of professional burnout ${ }^{*}$
}

\author{
M. Cevat YILDIRIM** Abdurrahman EKİNCI' ${ }^{* * *}$ \\ Ö. Murat ÖTER
}

\begin{abstract}
The purpose of this research is to determine the predictive power of organizational justice perceptions of education supervisor assistants, on the level of their professional burnout. In research, correlational survey model has been used. The population of research consists of all education supervisor assistants in Turkey $(\mathrm{N}=346)$. A method to extract sample has not been chosen by working on the population in general. Maslach Burnout Inventory - developed by Maslach and Jackson (1981) and adapted to Turkish by Ergin (1992), and Organizational Justice Scale - developed by Niehoff and Moorman (1993) and adapted to Turkish by Yildırım (2002) has been used as tools to collect data. Multiple linear regression analysis method has been used in data analysis. A significant relationship has been found between the variables of distributional, procedural, interactional justice and those of emotional exhaustion, depersonalization in research. Therefore, heads of education supervisors should pay attention to organizational justice matter in the practices.
\end{abstract}

Keywords: Education supervisor assistants, professional burnout, organizational justice, distributive justice, procedural justice.

\footnotetext{
${ }^{*}$ A part of this study was presented in $6^{\text {th }}$ National Education Management Congress.

Assist. Prof. Dr., Mardin Artuklu University, Faculty of Literature, Educational Sciences Department, Mardin, Turkey. E-mail:mcevatyildirim@gmail.com

Assist. Prof. Dr., Mardin Artuklu University, Faculty of Literature, Educational Sciences Department, Mardin, Turkey. E-mail: aekinci74@yahoo.com

Lecturer, Mardin Artuklu University, Faculty of Literature, Educational Sciences Department, Mardin, Turkey. E-mail: omermuratoter@hotmail.com
} 


\section{SUMMARY}

Purpose and Significance: There are many studies conducted about organizational justice both in education organizations and in other organizations (e.g. Aydın \& Karaman-Kepenekçi, 2008; Laçinoğlu, 2010; Liljegren \& Ekberg, 2009; Niehoff, \& Moorman, 1993; Polat, 2007; Polat ve Celep, 2008; Uğurlu, 2009). Many studies were conducted about professional burnout concerning education organizations and education supervisors (e.g. Arabac1 \& Akar, 2010; Balay \& Engin, 2007; Betoret, 2006; Y1lmaz, 2007). There are also several studies examining the relationship between organizational justice and professional burnout (e.g. Karaman, 2009; Kwak, 2006; Lambert et al., 2010; Liljegren \& Ekberg, 2009; Meydan, Basım \& Çetin, 2011; Yeniçeri, Demirel \& Seçkin, 2009). However, there is not any study about predictive power of organizational justice perception of education supervisor assistants, on the level of their professional burnout. The purpose of this research is to determine the predictive power of organizational justice perceptions of education supervisor assistants, on the level of their professional burnout.

Method: This study is a type of predictive correlation research. The population of research consists of all education supervisor assistants in Turkey $(\mathrm{N}=346)$. A method to extract sample has not been chosen by working on the population in general. Maslach Burnout Inventory developed by Maslach and Jackson (1981) and adapted to Turkish by Ergin (1992), and Organizational Justice Scale - developed by Niehoff and Moorman (1993) and adapted to Turkish by Yıldırım (2002) has been used as tools to collect data.120 education supervisor assistants did not want to fill in the data collection tool. 13 forms out of the all data collection forms handed back were not fully completed. So, just 213 data collection tools, which were suitable enough, were taken into evaluation (Balc1, 2005; Cohen Manion \& Morrison, 2005; Yazıcıŏglu ve Erdoğan, 2004). Multiple linear regression analysis method has been used in data analysis.

Results: It has been found out that education supervisor assistants' emotional exhaustion points and distributional, procedural, interactional justice variables have middle level and significant relationship. It has been understood that distributional justice variable is a significant predictor on emotional burnout. Education supervisor assistants' depersonalization points have been found to have a low level significance with distributional, procedural, interactional justice variables. It has been spotted that education supervisor assistants' low personal accomplishment feeling points have not 
any a significant relationship with distributional, procedural, interactional justice variables.

Discussion and Conclusions: In research, it has been understood that education supervisor assistants' emotional exhaustion and depersonalization points have a significant relationship with distributional, procedural, interactional justice. Distributional justice variable has been understood to be a significant predictor on emotional exhaustion. Therefore, heads of education supervisors must stand away from behaviors that could negatively affect the perception of organizational justice in matters such as distribution of tasks, reward- punishment, minding the views of individuals, communication. They should pay attention in detail to distributional justice in assigning examining and investigating tasks to education supervisors and education supervisor assistants. 


\title{
Eğitim Müfettiş Yardımcılarının Örgütsel Adalet Algılarının Mesleki Tükenmişlik Düzeylerine Etkisi*
}

\author{
M. Cevat YILDIRIM ${ }^{* *}$ Abdurrahman EKİNCi் $\dot{I}^{* * *}$ \\ Ö. Murat ÖTER ${ }^{* * * *}$
}

ÖZ. Bu araştırmanın amacı, eğitim müfettiş yardımcılarının örgütsel adalet algılarının, mesleki tükenmişlik düzeylerini yordama gücünü belirlemektir. Araştırmada ilişkisel tarama modelli kullanılmıştır. Araştırmanın evreni Türkiye genelindeki tüm eğitim müfettiş yardımcılarından oluşmaktadır $(\mathrm{N}=346)$. Evrenin geneli üzerinde çalışılarak, örneklem alma yoluna gidilmemiştir. Maslach ve Jackson (1981) tarafindan geliştirilen, Ergin (1992) tarafindan Türkçeye uyarlanan Maslach Tükenmişlik Ölçeği ile Niehoff ve Moorman (1993) tarafından geliştirilen Yıldırım (2002) tarafından Türkçe'ye uyarlanan Örgütsel Adalet Ölçeği, veri toplama aracı olarak kullanılmıştır. Verilerin analizinde çoklu doğrusal regresyon analizi yöntemi kullanılmıştır. Araştırmada dağıtımsal, işlemsel ve etkileşimsel adalet değişkenleri ile duygusal tükenme ve duyarsızlaşma değişkenleri arasında anlamlı bir ilişki olduğu saptanmıştır. $\mathrm{Bu}$ nedenle eğitim müfettişleri başkanları, uygulamalarında örgütsel adalete daha çok dikkat etmelidirler.

Anahtar Sözcükler: Eğitim müfettiş yardımcıları, mesleki tükenmişlik, örgütsel adalet, dağıtımsal adalet, işlemsel adalet.

\footnotetext{
*Bu araştırmanın bir bölümü VI. Ulusal Eğitim Yönetimi Kongresi’nde sözlü bildiri olarak sunulmuştur.

${ }^{* *}$ Yrd. Doç. Dr., Mardin Artuklu Üniversitesi, Edebiyat Fakültesi Eğitim Bilimleri Bölümü, Mardin, E-posta: mcevatyildirim@gmail.com

${ }^{* * *}$ Yrd. Doç. Dr., Mardin Artuklu Üniversitesi, Edebiyat Fakültesi Eğitim Bilimleri Bölümü, Mardin, Türkiye. E-posta: aekinci74@yahoo.com

**** Öğrt. Gör., Mardin Artuklu Üniversitesi, Edebiyat Fakültesi Eğitim Bilimleri Bölümü, Mardin, Türkiye. E-posta: omermuratoter@ hotmail.com
} 


\section{GíRIŞ}

Sosyal kurumların önemli erdemlerinden biri adalettir (Töremen ve Tan, 2010). Adalet kavramının geçmişi, Sokrates'e ve Platon'a kadar uzanmaktadır (Cevizci, 2010; Colquit, Conlon, Wesson, Porter \& Ng, 2001). Aslında bu kavramın geçmişinin insan geçmişi kadar uzun olduğu söylenebilir. Sınırlı kaynakların ve dağıtımın söz konusu olduğu her yerde, bu kavram olagelmiştir.

Adalet, herkesin hak ettiğini alması bir başka ifadeyle, hakkın gözetilmesi ve hayata geçirilmesidir. Düşünce tarihinde adaleti bir erdem olarak ilk ele alanlardan biri olan Platon'a göre adalet, başka insanlara hakkaniyetli davranmak ve herkese hak ettiğini vermektir. Sokrates ise dünyayı ayakta tutan gücün adalet olduğunu, adaletin unutulduğu yerde toplumların ve devletlerin varlıklarını sürdüremeyeceğini belirtmektedir (Cevizci, 2010). Adalet, toplumlar ve devletler için olduğu gibi örgütler için de önemli bir erdemdir. Bu nedenle adalet ile ilgili çeşitli araştırmalar yapılmıştır ve sonraları örgütsel adalet kavramı gündeme gelmiştir.

Örgütsel adalet kavramı, ilk kez 1987 yılında Greenberg tarafindan hakkaniyetin algılanması anlamında kullanılmıştır (Atalay, 2007; Colquit vd., 2001). Bu kavram, iş yaşamında bireylerin kendilerine karşı gösterilen eylemlerde adil davranılıp davranılmadığına ilişkin algılarını ve bu algıların bireylerin davranışları üzerine etkisini ifade etmektedir (Greenberg, 1990; Schmiesing, Safrit \& Gliem, 2003; Uğurlu, 2009). Bu kavram çoğunlukla; dağıtımsal, işlemsel ve etkileşimsel olmak üzere üç başlık altında ele alınmıştır (Chan, 2000; Cohen-Charash \& Spector, 2001; Yıldırım, 2007).

Dağıtımsal adalet kavramı, Adams'ın 1965 yılında geliştirdiği Hakkaniyet (equity) Kuramına dayanmaktadır. Bu kuram, bireyin kazanımlarını başkalarının kazanımlarıyla karşılaştırması ve bu kazanımlar arasında hakkaniyetin olup olmadığını incelemesi üzerinde durmuştur (Aydın \& Karaman-Kepenekçi, 2008; Yazıcıŏglu ve Topaloğlu, 2009). Dağıtımsal adalet, bireylerin elde ettikleri kazanımların adil dağıtılıp dağıtılmadığına ilişkin algılamaları ifade etmektedir (Chan, 2000; Folger \& Carpanzano, 1998; Cohen-Charasy \&Spector, 2001). İşlemsel adalet, kazanımların belirlenmesinde kullanılan yöntemlerin ve süreçlerin hakkaniyetine ilişkin algıyı ifade etmektedir (Chan, 2000; Cohen-Charasy \&Spector, 2001; Folger \& Carpanzano, 1998; Niehoff \& Moorman, 1993). Adalet ile ilgili çalışmalar 1975'e kadar dağıtımsal adalet konusunda yoğunlaşmıştır. İşlemsel adalet kavramına, Thibaut ve Walker'in 1975 yılındaki çalışmalarıyla birlikte ilgi gösterilmeye başlanmıştır (Colquit vd., 2001; Liljegren \& Ekberg, 2009; Y1ldırım, 2003, 2007). Bies ve Moag'ın 1986 yılındaki çalışmalarıyla birlikte adalet literatüründe, etkileşimsel adalet 
konusuna da yer verilmeye başlanmıştır (Atalay, 2007; Colquit vd., 2001). Etkileşimsel adalet, karar alma sürecinde bireylere kararın nasıl söylendiği ile ilgili bir kavramdır (Erkanl1, 2009; Moorman, 1991). Bu kavram, işlemlerin uygulanmasında bireyler arası iletișimin adilliği ve ilişkilerin niteliğine ilişkin algıyı ifade etmektedir (Cohen-Charash \& Spector, 2001; Folger \& Cropanzano, 1998; Moorman, 1991; Polat, 2007; Y1ldırım, 2007). Etkileşimsel adalet, işlemleri uygulamakla görevli kişilerin karşı tarafa gösterdikleri tutum ve davranışlarla ilgili olduğundan, işlemsel adalete bağlı bir ek boyut olarak geliştirilmiştir (Söyük, 2007, 13). Dağıtımsal, işlemsel ve etkileşimsel adalet kavramlarının üçünde de bireylerin, örgütte hakkaniyetin olup olmadığına ilişkin algılarının konu edinildiği söylenebilir. Örgütsel adalete ilişkin algının, hem örgütü hem de işgörenleri çeşitli açılardan etkilediği ifade edilebilir.

Örgütsel adalet, bireyleri birbirine ve örgüte yakınlaştırırken örgütsel adaletsizlik ise bireyleri birbirinden ve örgütten uzaklaştırmaktadır (Söyük, 2007). Yapılan araştırmalarda bireylerin örgütsel adalet algılarının; iş doyumu, örgütsel bağl1lık, örgütsel yurttaşlık, güven duyma, iş performansı, işten ayrılma niyeti vb. algılarıyla ilişkisi bulunmuştur (Colquit vd., 2001; Folger \& Cropanzano, 1998; Gürpınar, 2006; Irak, 2004; Laçinoğlu, 2010; Nowakowski \& Conlon, 2005; Polat, 2007; Uğurlu, 2009). Son y1llarda yapılan araştırmalarda ise bireylerin örgütsel adalet algıları ile tükenmişlik düzeyleri arasında negatif bir ilişkinin olduğu saptanmıştır (Çakır, 2009; Karaman, 2009; Liljegren \& Ekberg, 2009; Yeniçeri, Demirel ve Seçkin, 2009).

Tükenmişlik kavramı, ilk kez 1961 yılında Greene tarafından kullanılmıştır ve 1970'li yıllardan itibaren araştırmalara konu olmuştur (Maslach, Schaufeli \& Leiter, 2001, 398). Bu kavram, ilk kez 1974 y1lında Freudenberger tarafından; başarısızlık, yıpranma, enerji ve güç kaybı veya insanın iç kaynakları üzerinde, karşılanamayan isteklerden dolayı tükenmeye başlama durumu olarak tanımlanmıştır (Izgar, 2003; Peker, 2002). Freudenberger, tükenmişliğin sadece duygusal boyutunu ele almıştır (Sağlam-Arı ve Çına-Bal, 2008). Tükenmişlik (mesleki tükenmişlik) kavramı, Maslach ve Jackson tarafindan 1981 yılında ayrıntılı ifade edilmiş ve tükenmişliğin üç boyutlu olduğu saptanmıştır (Maslach \& Jackson, 1981; Ergin, 1992). Onlara göre mesleki tükenmişlik, insanlarla yoğun ilişki içerisinde olan bireylerde kronik bir stres sürecinden sonra ortaya çıkan fiziksel ve duygusal enerji azalması durumudur (Maslach \& Jackson, 1981; Maslach vd., 2001; Tümkaya, 2000). Mesleki tükenmişliğin boyutları ise duygusal tükenme, duyarsızlaşma ve kişisel başarı (düşük kişisel başarı duygusu) şeklinde ele alınmıştır (Izgar, 2003; Maslach \& Jackson, 1981; Maslach vd., 2001). 
Duygusal tükenme, bireylerin iş yaşamında, halsizlik ve aşırı yorgunluk belirtileriyle birlikte kendilerini duygusal yönden yıpranmış hissetmelerine ve bireysel strese yol açan bir durumdur (Kan, 2008; Maslach \& Jackson, 1981; Maslach vd., 2001). Duyarsızlaşma kavramına bakıldığında, bu kavram, tükenmişliğin bireylerarası boyutuna yönelik olup, bireyin işine ve hizmet verilen alanlarda bireylere karşı olumsuz duygular ve tepkiler geliştirmesi olarak tanımlanmıştır (Balay ve Engin, 2007; Maslach \& Jackson, 1981). Düşük kişisel başarı duygusu ise bireyin kendisini işinde yetersiz ve başarısız olarak değerlendirme eğiliminde olmasını ifade etmektedir (Izgar, 2003; Budak ve Sürgevil, 2005; Maslach vd., 2001).

Mesleki tükenmişliğin, bireyler üzerinde; fiziksel, psikolojik ve sosyal açılardan birçok olumsuz etkilere yol açtığı söylenebilir. Mesleki tükenmişliği olumsuz yönde etkileyen çeşitli faktörler vardır. Girgin bu faktörleri, motivasyon eksikliği, fazla iş yükü, üstleri tarafından takdir edilmeme, sosyal desteklerin azlığı, iş ortamının beklentilerini karşılayamaması ve rol karmaşası şeklinde sıralamıştır (Girgin, 1995, 2010). $\mathrm{Bu}$ faktörlerin yanı sıra, örgütsel adalete ilişkin algının da mesleki tükenmişliğe etkisinin olduğu söylenebilir. Yapılan araştırmalarda, örgütsel adalet algısı ile mesleki tükenmişlik düzeyi arasında negatif bir ilişki olduğu (Çakır, 2009; Kwak, 2006; Liljegren \& Ekberg, 2009; Maslach \& Leiter, 2008) ve örgütsel adalet algısının mesleki tükenmişliği etkilediği saptanmıştır (Maslach \& Leiter, 1997, akt. Budak ve Sürgevil, 2005; Lambert vd., 2010; Meydan, Basım ve Çetin, 2011; Teper, 2001, akt. Halbesleben \& Buckley, 2004).

Literatüre bakıldığında Türkiye'de ve dünyada örgütsel adalet konusunda gerek eğitim örgütlerinde gerekse diğer örgütlerde çok sayıda çalışma yapılmıştır (örn. Aydın \& Karaman-Kepenekçi, 2008; Laçinoğlu, 2010; Liljegren \& Ekberg, 2009; Niehoff, \& Moorman, 1993; Polat, 2007; Polat ve Celep, 2008; Uğurlu, 2009). Mesleki tükenmişlik konusunda ise eğitim örgütleri ve eğitim müfettişleri ile ilgili çok sayıda çalışma yapılmıştır (örn. Arabacı ve Akar, 2010; Balay ve Engin, 2007; Betoret, 2006; Y1lmaz, 2007). Örgütsel adalet ve mesleki tükenmişlik ile ilgili çeşitli ilişkisel araştırmalar da yapılmıştır (örn. Karaman, 2009; Kwak, 2006; Lambert vd., 2010; Liljegren \& Ekberg, 2009; Meydan vd., 2011; Yeniçeri vd., 2009). Fakat literatürde, "eğitim müfettiş yardımcılarının örgütsel adalet algılarının, mesleki tükenmişlik düzeylerini yordama gücü" hakkında yapılmış herhangi bir çalışmaya ise rastlanmamıştır. Bu araştırma kapsamındaki eğitim müfettiş yardımcılarının, eğitim müfettiş yardımcılı̆̆ı görevindeki deneyimleri az olsa da, onlar atanmadan önce eğitim kurumlarında genel olarak en az sekiz yıl görev yapmışlardır. Ayrıca, eğitim müfettiş yardımcılığı görevine atanmayı takip eden ilk aylardan itibaren eğitim 
müfettişlerine verilen görevlerin hepsi eğitim müfettiş yardımcılarına da yaptırılabilmektedir (MEB, 1999, 2011). Dolayısıyla eğitim müfettiş yardımcılarının yeni bir göreve atanmış olmalarının, göreve başlar başlamaz eğitim müfettişlerinin yaptıkları bütün görevleri yapmalarının ve farklı yeni görevleri (örn. İnceleme, soruşturma) yerine getirmelerinin, onların örgütsel adalet algısı ve mesleki tükenmişlik düzeyleri üzerine çeşitli etkileri olabileceği düşünülmüştür. Eğitim müfettiş yardımcılarının; bu süreçte yaşadığı sorunların ya da karşılaştığı durumların, hem eğitim müfettiş yardımcılığ 1 dönemlerini, hem de gelecekteki mesleki yaşamlarını etkileyeceği söylenebilir. $\mathrm{Bu}$ nedenlerle, bu konunun eğitim müfettiş yardımcıları açısından araştııılmasının yararlı olacağı düşünülmüştür.

$\mathrm{Bu}$ araştırmanın amacı, "Eğitim müfettiş yardımcılarının örgütsel adalet algılarının, mesleki tükenmişlik düzeylerini yordama gücünü" belirlemektir. Bu amaca yönelik olarak aşağıdaki sorulara cevap aranmıştır:

1. Eğitim müfettiş yardımcılarının dağıtımsal, işlemsel ve etkileşimsel adalete ilişkin algıları, duygusal tükenme düzeylerinin anlamlı bir yordayıcisı midır?

2. Eğitim müfettiş yardımcılarının dağıtımsal, işlemsel ve etkileşimsel adalete ilişkin algıları, duyarsızlaşma düzeylerinin anlamlı bir yordayicisi midir?

3. Eğitim müfettiş yardımcılarının dağıtımsal, işlemsel ve etkileşimsel adalete ilişkin algıları, düşük kişisel başarı duygusu düzeylerinin anlamlı bir yordayıcisı midir?

\section{YÖNTEM}

Araştırmanın modeli, evren ve örneklem, veri toplama araçları ve verilerin analizi ile ilgili açıklamalar aşağıda yapılmıştır.

\section{Araştırmanın Modeli}

$\mathrm{Bu}$ araştırmada, ilişkisel araştırma modeli kullanılmıştır (Balcı, 2005; Cohen, Manion, \& Morrison, 2005). Örgütsel adaletin, mesleki tükenmişliğe etkisi araştırıldığından bu araştırma, yordayıcı ilişki araştırması türündedir (Büyüköztürk, Çakmak, Akgün, Karadeniz ve Demirel, 2008).

\section{Evren ve Örneklem}

Araştırmanın evreni, Türkiye genellindeki tüm eğitim müfettiş̧ yardımcılarından oluşmaktadır $(\mathrm{N}=346)$. Araştırma evrenindeki eğitim müfettiş yardımcılarının sayısının çok fazla olmaması nedeniyle ve 
güvenirliği daha yüksek verilerin elde edilmesi amacıyla evrenin geneli üzerinde çalışılarak örneklem alma yoluna gidilmemiştir. Veri toplama aracı, tüm eğitim müfettiş yardımcılarının 20-31 Aralık 2010 tarihleri arasında Erzurum Hizmetiçi Eğitim Enstitüsü'nde zorunlu olarak katıldıkları hizmetiçi eğitim kursunda uygulanmıştır. Araştırma kapsamındaki eğitim müfettiş yardımcılarından 120'si veri toplama aracını doldurmak istemediklerini belirtmişlerdir. Doldurulan veri toplama araçlarından 13'ü ise eksik doldurulduğundan değerlendirme dışı bırakılmıştır. Dolayısıyla 213 eğitim müfettiş yardımcısının doldurduğu veri toplama aracı değerlendirilmeye alınmıştır. $\mathrm{Bu}$ nedenle, çalışma evreni "kendini örnekleyen evren" olarak kabul edilmiştir (Çilenti, 1994: 167). Araştırmada $\% 5^{\prime}$ 'lik belirlilik düzeyi başka bir ifadeyle \% 95'lik güven düzeyi temel alınmıştır. Dolayısıyla değerlendirmeye alınan 213 veri toplama aracı, evreni temsil edebilecek düzeydedir (Balc1, 2005; Cohen vd., 2005; Yazıcığlu ve Erdoğan, 2004).

\section{Veri Toplama Araçları}

Araştırmada, Maslach ve Jackson (1981) tarafından geliştirilen, Ergin (1992) tarafindan Türkçe'ye uyarlanan "Maslach Tükenmişlik Ölçeği (MTÖ)" ile Niehoff ve Moorman (1993) tarafından geliştirilen ve Yıldırım (2002) tarafindan Türkçe'ye uyarlanan "Örgütsel Adalet Ölçeği (ÖAÖ)" veri toplama aracı olarak kullanılmıştır.

Ergin (1992)'in Türkçe'ye uyarladığı MTÖ, likert tipi beşli dereceleme biçiminde hazırlanmış toplam 22 maddeden ve üç boyuttan oluşmaktadır. Boyutlardan birincisi, dokuz maddeden oluşan "duygusal tükenme"; ikincisi, beş maddeden oluşan "duyarsızlaşma", üçüncüsü ise sekiz maddeden oluşan "kişisel başarı" alt boyutudur. Ölçeğin alt boyutlarının iç tutarlılık katsayıları, sırasıyla ".83”, “.65” ve “.72” olarak saptanmıștır. Bu araştırmada ise MTÖ'nün alt boyutlarının iç tutarlılık katsayıları sırasıyla “.87”, “.69” ve ".77”olarak bulunmuştur.

Yıldırım (2002)'ın Türkçe’ye uyarladığ1 ÖAÖ ise likert tipi beşli dereceleme şeklinde hazırlanmış toplam 20 maddeden ve üç boyuttan oluşmaktadır. Boyutlardan birincisi, beş maddeden oluşan "dağıtımsal adalet"; ikincisi, altı maddeden oluşan "işlemsel adalet", üçüncüsü ise dokuz maddeden oluşan "etkileşimsel adalet" alt boyutudur. Ölçeğin alt boyutlarının iç tutarlılık katsayıları sırasıyla ".81", ".89" ve ".95" olarak saptanmıştır (Yıldırım, 2003, 2007). Bu araştırmada, ÖAÖ'nün alt boyutlarının iç tutarlılık katsayıları sırasıyla “.79”, “.93” ve “.96” olarak bulunmuştur. 


\section{Verilerin Analizi}

Veriler analiz edilirken mesleki tükenmişliğin kișisel başarı boyutuna ait puanlar, duygusal tükenme ve duyarsızlaşma boyutlarının tersi şeklinde puanlanmıştır. Bu nedenle araştırmada, "kişisel başarı" adlandırması yerine "düşük kişisel başarı duygusu" adlandırması kullanılmıştır. Verilerin analizi, SPSS-16 paket programıla yapılmıştır. Verilerin analizinde, çoklu doğrusal regresyon analizi yöntemi kullanılmıştır. Öncellikle çoklu doğrusal regresyon analizinin varsayımları test edilmiştir. Varsayımların karşılandığ 1 tespit edildikten sonra, regresyon analizi yapılmıştır Regresyon analizinde, bütün bağımsız değişkenlerin birlikte analize dâhil edildiği "Enter" yöntemi kullanılmıştır. Anlamlılık düzeyi, $\mathrm{p}<, 05$ olarak kabul edilmiştir (Altunışık, Coşkun, Bayraktaroğlu ve Yıldırım, 2005; Büyüköztürk, 2002; Çokluk, Şekercioğlu ve Büyüköztürk, 2010; Kalayc1, 2009).

\section{BULGULAR}

Bulgular, araştırmanın alt amaçları doğrultusunda aşağıda açıklanmıştır. Eğitim müfettiş yardımcılarının dağıtımsal, işlemsel ve etkileşimsel adalete ilişkin algılarının, duygusal tükenme düzeylerini yordamasına ilişkin çoklu doğrusal regresyon analizi sonuçları Tablo 1'de verilmiştir.

Tablo 1. Duygusal tükenmenin yordanmasina iliş̧kin çoklu doğrusal regresyon analizi sonuçları

\begin{tabular}{lccccccc}
\hline Değişken & $\mathrm{B}$ & $\begin{array}{c}\text { St. } \\
\text { hata }\end{array}$ & $\beta$ & $\mathrm{t}$ & $\mathrm{p}$ & $\begin{array}{c}\text { İkili } \\
\mathrm{r}\end{array}$ & $\begin{array}{c}\text { Kısmi } \\
\mathrm{r}\end{array}$ \\
\hline Sabit & 3,170 &, 192 & - & 16,476 &, 000 & - & - \\
Dağıtımsal adalet &,- 172 &, 065 &,- 202 & $-2,652$ &, 009 &,- 301 &,- 180 \\
İşlemsel adalet &,- 121 &, 088 &,- 173 & $-1,367$ &, 173 &,- 295 &,- 094 \\
Etkileşimsel adalet &,- 016 &, 091 &,- 021 &,- 174 &, 862 &,- 256 &,- 012 \\
\hline $\mathrm{F}=9,243 ; \mathrm{p}=, 000 ; \mathrm{R}=, 342 ; \mathrm{R}^{2}=, 117$ & & & & & &
\end{tabular}

Tablo 1'e göre, "dağıtımsal, işlemsel ve etkileşimsel adalet" değişkenleri ile duygusal tükenme arasında negatif bir ilişki vardır. Adı geçen üç yordayıcı değişkenin birlikte, eğitim müfettiş yardımcılarının duygusal tükenme puanları ile orta düzeyde ve anlamlı bir ilişkiye sahip olduğu $\left(\mathrm{R}^{2}=, 117 ; \mathrm{F}=9,243 ; \mathrm{p}=, 000\right)$ ve duygusal tükenmedeki toplam varyansın yaklaşık \%12'sini açıkladığı anlaşılmaktadır. Standardize edilmiş regresyon katsayısına $(\beta)$ göre, yordayıcı değişkenlerin duygusal tükenme üzerindeki göreli önem sırası; "dağıtımsal adalet, işlemsel adalet, etkileşimsel adalet" şeklindedir. Regresyon katsayılarının anlamlılığına 
ilişkin, " $t "$ değerlerine bakıldığında; dağıtımsal adalet değişkeninin, duygusal tükenme üzerinde anlamlı bir yordayıcı olduğu görülmektedir $(\mathrm{p}=, 009)$. Ancak işlemsel ve etkileşimsel adalet değişkenlerinin, duygusal tükenme üzerinde anlamlı bir yordayıcı olmadığı anlaşılmaktadır. Dolayısıyla, eğitim müfettiş yardımcılarının dağıtımsal adalet konusunda daha hassas oldukları ve bu nedenle dağıtımsal adalet algısının, duygusal tükenme düzeyleri üzerinde anlamlı bir yordayıcı olduğu söylenebilir.

Eğitim müfettiş yardımcılarının dağıtımsal, işlemsel ve etkileşimsel adalete ilişkin algılarının, duyarsızlaşma düzeylerini yordamasına ilişkin çoklu doğrusal regresyon analizi sonuçları Tablo 2'de verilmiştir.

Tablo 2. Duyarsızlaşmanın yordanmasına ilişkin çoklu regresyon analizi

\begin{tabular}{|c|c|c|c|c|c|c|c|}
\hline Değişken & B & $\begin{array}{c}\text { St. } \\
\text { hata }\end{array}$ & $\beta$ & $\mathrm{t}$ & $\mathrm{p}$ & $\begin{array}{c}\text { İkili } \\
\text { r }\end{array}$ & $\begin{array}{c}\text { Kismi } \\
\text { r }\end{array}$ \\
\hline Sabit & 2,444 &, 188 & - & 12,973 &, 000 & - & - \\
\hline Dağıtımsal adalet &,- 086 &, 063 &,- 107 & $-1,354$ &, 177 &,- 181 &,- 093 \\
\hline İşlemsel adalet &,- 045 &, 086 &,- 068 &,- 522 & ,602 &,- 196 &,- 036 \\
\hline Etkileşimsel adalet &,- 061 & 089 &,- 086 &,- 687 & ,493 &,- 191 &,- 047 \\
\hline
\end{tabular}

Tablo 2'ye göre, "dağıtımsal, işlemsel ve etkileşimsel adalet" değişkenleri ile duyarsızlaşma arasında negatif bir ilişki vardır. Adı geçen üç yordayıcı değişkenin birlikte, eğitim müfettiş yardımcılarının duyarsızlaşma puanları ile düşük düzeyde anlamlı bir ilişkiye sahip olduğu anlaşılmaktadır $\left(\mathrm{R}^{2}=, 049 ; \quad \mathrm{F}=3.608 ; \quad \mathrm{p}=, 014\right)$. Yordayıc1 değişkenler birlikte, duyarsızlaşmadaki toplam varyansın yaklaşık \%5'ini açıklamaktadır. $\beta$ değerlerine bakıldığında yordayıcı değişkenlerin, duyarsızlaşma üzerindeki göreli önem sırası; "dağıtımsal adalet, etkileşimsel adalet, işlemsel adalet" şeklindedir. Regresyon katsayılarının anlamlılığına yönelik "t" değerleri incelendiğinde; dağıtımsal, işlemsel ve etkileşimsel adalet değişkenlerinin üçünün de duyarsızlaşma üzerinde anlamlı bir yordayıcı olmadığı görülmektedir.

Eğitim müfettiş yardımcılarının dağıtımsal, işlemsel ve etkileşimsel adalete ilişkin algılarının, düşük kişisel başarı duygusu düzeylerini yordamasına ilişkin çoklu doğrusal regresyon analizi sonuçları Tablo 3'te verilmiştir.

Tablo 3'e bakıldığında, "dağıtımsal, işlemsel ve etkileşimsel adalet" değişkenleri ile düşük kişisel başarı duygusu arasında negatif bir ilişkinin olduğu görülmektedir. Ancak, adı geçen üç yordayıcı değişkenin birlikte, eğitim müfettiş yardımcılarının düşük kişisel başarısızlık duygusu puanları ile anlamlı bir ilişkiye sahip olmadığ 1 anlaşılmaktadır $\left(\mathrm{R}^{2}=, 012 ; \mathrm{F}=, 811\right.$; 
$\mathrm{p}=$,489). Yordayıcı değişkenler birlikte, düşük kişisel başarı duygusundaki toplam varyansın yaklaşık \% 1,2'sini açıklamaktadır. Model bir bütün olarak anlamlı olmadığından yordayıcı değişkenlere ilişkin katsayıların yorumlanmasına gerek olmadığı düşünülmüştür.

Tablo 3. Düşük kişisel başarı duygusunun yordanmasına ilişkin çoklu

\begin{tabular}{lcccccccc}
\multicolumn{7}{c}{ doğrusal regresyon analizi sonuçlart } \\
\hline \multicolumn{1}{c}{ Değişken } & $\mathrm{B}$ & $\begin{array}{c}\text { St. } \\
\text { hata }\end{array}$ & $\beta$ & $\mathrm{t}$ & $\mathrm{p}$ & İkili & \multicolumn{2}{c}{ Kismi } \\
& & & & & $\mathrm{r}$ & $\mathrm{r}$ \\
\hline Sabit & 2,650 &, 160 & - & 16,590 &, 000 & - & - \\
Dağıtımsal adalet &,- 023 &, 054 &,- 034 &,- 428 &, 669 &,- 078 &,- 030 \\
İşlemsel adalet &,- 024 &, 073 &,- 044 &,- 331 &, 741 &,- 100 &,- 023 \\
Etkileşimsel adalet &, 027 &, 075 &, 045 &,- 353 &, 725 &,- 098 &, 024 \\
\hline $\mathrm{F}=, 811 ; \mathrm{p}=, 489 ; \mathrm{R}=, 107 ; \mathrm{R}^{2}=, 012$ & & & & &
\end{tabular}

\section{TARTIŞMA VE SONUÇ}

$\mathrm{Bu}$ araştırma, eğitim müfettiş yardımcılarının örgütsel adalet algılarının, mesleki tükenmişlik düzeylerini yordama gücünü belirlemek üzere gerçekleştirilmiş̧ir. Araştırmada, eğitim müfettişlerinin dağıtımsal, işlemsel ve etkileşimsel adalet algıları ile duygusal tükenme ve duyarsızlaşma düzeyleri arasında anlamlı bir ilişki olduğu saptanmıştır. Ünal ve Kantar (2011)'ın araştırmasındaki, eğitim müfettiş yardımcılarının sorunları ile eğitim müfettişlerinin sorunları benzer olduğu sonucu temel alınarak, öneriler hem eğitim müfettişlerini hem de eğitim müfettiş yardımcılarını kapsayacak şekilde geliştirilmiştir.

Eğitim müfettiş yardımcılarının dağıtımsal, işlemsel ve etkileşimsel adalet değişkenlerine ilişkin algıları ile duygusal tükenme düzeyleri arasında negatif ve orta düzeyde anlamlı bir ilişki olduğu saptanmıştır. Üç değişkenin birlikte, duygusal tükenmedeki toplam varyansın yaklaşık \%12'sini açıkladığ1 anlaşılmıştır. Sözü edilen üç değişkenden sadece dağıtımsal adalet değişkeninin, duygusal tükenme üzerinde anlamlı bir yordayıcı olduğu görülmüş̧ür. Buna göre, eğitim müfettiş yardımcılarının dağıtımsal adalete ilişkin algılarının, duygusal tükenme düzeyleri üzerinde diğer iki değişkenden daha fazla etkili olduğu söylenebilir. Özellikle görev dağılımının adil olarak yapılmasının eğitim müfettiş yardımcılarının duygusal tükenme düzeyleri üzerinde önemli etkilerinin olduğu ifade edilebilir. Nitekim Söbü (2005)'nün yaptığ1 araştırmada, eğitim müfettişlerine verilen inceleme ve soruşturma görevlerinin yeterince dengeli ve adil dağıtılmadığı saptanmıştır. Örgütsel adalet ve mesleki tükenmişlik ile ilgili yapılan ilişkisel araştırmalara bakıldığında; Karaman (2009)'ın araştırmasında, öğretmenlerin örgütsel adaletin alt boyutlarına ilişkin algıları ile duygusal tükenme düzeyleri arasında negatif bir ilişki olduğu 
saptanmıştır. Yeniçeri ve diğerleri (2009) araştırmalarında, dağıtımsal ve etkileşimsel adalet algısı ile duygusal tükenme düzeyi arasında negatif bir ilişkinin olduğunu ve örgütsel adaletin adı geçen iki alt boyutunun, duygusal tükenmeye olumsuz etkisinin olduğunu tespit etmişlerdir. Meydan ve diğerleri (2011) araştırmalarında, dağıtımsal adaletin duygusal tükenme üzerinde doğrudan anlamlı bir yordayıcı olduğunu saptamışlardır. Maslach ve Leiter (2008)'in araştırmalarında ise adil olma (fairness) ile tükenme arasında orta düzeyde negatif bir ilişkinin olduğu belirlenmiştir. Bütün bu sonuçlar, araştırmanın yukarıda sözü edilen sonuçlarıyla örtüşmektedir. Bununla birlikte araştırmanın söz konusu sonuçlarıyla örtüşmeyen araştırma sonuçları da bulunmaktadır. Yeniçeri ve diğerleri (2009) imalat sanayi çalışanlarıyla ilgili araştırmalarında, işlemsel adalet ile duygusal tükenme arasında pozitif bir ilişki olduğunu saptamışlardır. Meydan ve diğerleri (2011) ise çeşitli bakanlıkların yöneticileriyle ilgili araştırmalarında işlemsel adaletin de duygusal tükenme üzerinde doğrudan anlamlı bir yordayıcı olduğunu tespit etmişlerdir. $\mathrm{Bu}$ farklı sonuçların, eğitim müfettiş̧ yardımcılarının çalışma şekilleri ve mesleki özelliklerinden kaynaklandığg söylenebilir. Çünkü eğitim müfettişlerinin ve eğitim müfettiş yardımcılarının görevlerini yerine getirme şekli diğer (yönetici, öğretmen, memur gibi) çalışanlardan farklıdır. Eğitim müfettişleri, genel olarak yapacakları çalışmalara ilişkin esnek bir planlama yapmaktadırlar ve çalışmalarını bağımsız bir şekilde yürütmektedirler (MEB, 1999, 2011). Bu nedenle işlemsel adalet algısının onların duygusal tükenmeleri üzerinde anlamlı bir yordayıcı olmadığı söylenebilir. Diğer taraftan, eğitim müfettişlerinin ve eğitim müfettiş yardımcılarının iş yüklerinin (Özmen ve Şahin, 2010; Ünal ve Kantar, 2011; Yıldırım, Beycioğlu, Uğurlu ve Sincar, 2011) ve görev alanlarının fazla olması (Yıldırım, 2009), maaşlarının az olması (Ünal ve Kantar, 2011), geçici görev yolluklarının zamanında ödenmemesi (Özmen ve Şahin, 2010; Ünal ve Kantar, 2011) ve eğitim müfettiş yardımcılarının erken yetkilendirilmesi yani göreve başlar başlamaz kendilerine inceleme ve soruşturma görevinin verilmesi (Ünal ve Kantar, 2011) gibi sorunlar eğitim müfettiş yardımcılarının dağıtımsal adalet algılarının, duygusal tükenmeleri üzerinde anlamlı bir yordayıcı olmasına neden olduğu söylenebilir.

Eğitim müfettiş yardımcılarının dağıtımsal, işlemsel ve etkileşimsel adalet değişkenlerine ilişkin algıları ile duyarsızlaşma düzeyleri arasında negatif ve düşük düzeyde anlamlı bir ilişki olduğu tespit edilmiştir. Bu üç değişkenin birlikte, duyarsızlaşmadaki toplam varyansın yaklaşı \%5'ini açıkladığ 1 anlaşılmıştır. Örgütsel adaletin boyutlarının hiçbirisinin tek başına duyarsızlaşma üzerinde anlamlı bir yordayıc1 olmadığ 1 belirlenmiştir. Araştırmanın bu sonuçlarını destekleyen araştırmalara bakıldığında; Karaman (2009)'ın araştırmasında, ögretmenlerin örgütsel adaletin alt boyutlarına ilişkin algıları ile duyarsızlaşma düzeyleri arasında negatif yönlü bir ilişki olduğu belirlenmiştir. Maslach ve Leiter (2008)'in araştırmalarında 
ise adalet algısı ile duyarsızlaşma arasında orta düzeyde negatif bir ilişki olduğu saptanmıştır. Benzer ve örtüşen araştırma sonuçlarına karşın farklılık gösteren araştırma sonuçları da bulunmaktadır. Meydan ve diğerleri (2011) araştırmalarında, dağıtımsal ve işlemsel adaletin duyarsızlaşma üzerinde doğrudan anlamlı bir yordayıcı olduğunu saptamışlardır. Bu örtüşmeyen sonuçlara ilişkin olarak: Eğitim müfettiş yardımcılarının dağıtımsal ve işlemsel adalet algıları ile duyarsızlaşma düzeyleri arasında negatif ilişki olsa da, eğitim müfettiş yardımcıları yeni bir göreve başlamış olmanın heyecanını yaşadıklarından ve onların mesleki özelliklerinin farklılığından dolayı sözü edilen değişkenlere ilişkin algılarının duyarsızlaşma düzeyleri üzerinde anlamlı bir yordayıcı olmadığ 1 söylenebilir.

Eğitim müfettiş yardımcılarının dağıtımsal, işlemsel ve etkileşimsel adalet değişkenlerine ilişkin algıları ile düşük kişisel başarı duygusu düzeyleri arasında negatif bir ilişkinin olduğu; ancak bu değişkenlerin, onların düşük kişisel başarı duygusu düzeyleri üzerinde anlamlı bir yordayıcı olmadığ 1 anlaşılmıştır. Bu sonuçlarla benzerlik gösteren Karaman (2009)'ın araştırmasında da, öğretmenlerin örgütsel adaletin alt boyutlarına ilişkin algıları ile düşük kişisel başarı duygusu düzeyleri arasında negatif bir ilişkinin olduğu tespit edilmiştir. Meydan ve diğerlerinin (2011) araştırmalarında ise yöneticilerin dağıtımsal, işlemsel ve etkileşimsel adalet algılarının, düşük kişisel başarı duyguları üzerinde anlamlı bir yordayıcı olmadığı saptanmıştır. Bu sonuçlar araştırmanın sonuçlarıyla örtüşmektedir. Araştırmanın üç alt amacı doğrultusunda yukarıda tartışılan sonuçlara bakıldığında, eğitim müfettiş yardımcılarının mesleki tükenmişlik düzeylerini etkileyen başka faktörlerin de olduğu ve örgütsel adalet algısının bu faktörlerden sadece biri olduğu anlaşılmaktadır.

Araştırmanın sonuçları doğrultusunda uygulayıcılara şu önerilerde bulunulabilir: Genel anlamda eğitim örgütlerinin yöneticileri özel anlamda ise eğitim müfettişleri başkanları, uygulamalarında örgütsel adalete daha çok dikkat etmelidirler. Eğitim müfettişleri başkanları, görev dağılımı, ödül-ceza, bireylerin görüşlerini önemseme, iletişim vb. konularda, bireylerin örgütsel adalet algısını olumsuz etkileyecek davranışlardan uzak durmalıdırlar. Eğitim müfettişlerine ve eğitim müfettiş yardımcılarına inceleme ve soruşturma görevlerini dengeli ve adil bir biçimde vermeye özen göstermelidirler. Eğitim müfettişlerinin ve eğitim müfettiş yardımcılarının görev yapacakları teftiş gruplarının ve teftiş bölgelerinin belirlenmesinde adaletli olmaya dikkat etmelidirler. Eğitim müfettişlerinin ve eğitim müfettiş̧ yardımcılarının geçici görev yollukları zamanında ödenmelidir. Eğitim müfettişlerinin ve eğitim müfettiş yardımcılarının iş yükleri azaltılmalıdır. Buna yönelik olarak, okul yöneticilerinin yapabilecekleri inceleme ve soruşturma işlerinin okul yöneticileri tarafindan yapılması ya da yaptırılması sağlanmalıdır. Böylece, eğitim müfettişlerinin ve eğitim müfettiş yardımcılarının genel anlamda örgütsel adalet özel anlamda ise dağıtımsal 
adalet algılarının artacağı ve mesleki tükenmişlik düzeylerinin azalacağ1 söylenebilir.

Araştırmacılara yönelik ise şu önerilerde bulunulabilir: Eğitim müfettiş ve eğitim müfettiş yardımcılarının iş yüklerinin ya da görev alanlarının, örgütsel adalet ya da dağıtımsal adalet algılarına ve mesleki tükenmişlik düzeylerine etkisi araştırılmalıdır. Eğitim müfettişlerinin ve eğitim müfettiş yardımcılarının örgütsel adalet ya da dağıtımsal adalet algılarına ve mesleki tükenmişlik düzeylerine ilişkin nitel araştırmalar yapılmalıdır. Böylece onların örgütsel adalet ya da dağıtımsal adalet algılarını ve mesleki tükenmişlik düzeylerini olumsuz etkileyen durumların daha derinlemesine tespit edilmesi sağlanmış olacaktır.

\section{KAYNAKLAR}

Altunışık, R., Coşkun, R., Bayraktaroğlu, S. ve Yıldırım, E. (2005). Sosyal Bilimlerde Araştırma Yöntemleri SPSS Uygulamalı. Sakarya: Sakarya Kitabevi.

Arabacı, İ. B. ve Akar, H. (2010). Eğitim müfettişlerinin bazı sosyal, demografik ve mesleki özelliklerine göre mesleki tükenmişlik düzeylerinin belirlenmesi. Dicle Üniversitesi Ziya Gökalp Ë̆itim Fakültesi Dergisi, 15, 78-91.

Atalay, D. D. (2007). Denklik duyarlılı̆̆ açısından algılanan örgütsel adalet-örgütsel bağlanma ilişkisi. Yayımlanmamış doktora tezi, Ankara Üniversitesi Sosyal Bilimler Enstitüsü, Ankara.

Aydın, I. \& Karaman-Kepenekci, Y. (2008). Principals' opinions of organisational justice in elementary schools in Turkey. Journal of Educational Administration, 46 (4), 497-513.

Balc1, A. (2005). Sosyal Bilimlerde Araştırma Yöntem, Teknik ve İlkeler. Ankara: Pegem A Yayıncıllk.

Balay, R. ve Engin, A. (2007). GAP Bölgesinde görev yapan ilköğretim müfettişlerinin tükenmişlik düzeyi üzerine bir araştırma. Ankara Üniversitesi Ĕgitim Bilimleri Fakültesi Dergisi, 40 (2), 205-232.

Betoret, F. D. (2006). Stressors, self-efficacy, coping resources, and burnout among secondary school teachers in Spain. Educational Psychology, 26 (4), 519-539.

Büyüköztürk, Ş. (2002). Sosyal Bilimler İçin Veri Analizi El Kitabı. Ankara: Pegem A Yayıncilık.

Büyüköztürk, Ş., Çakmak, E. K., Akgün, Ö. E., Karadeniz, Ş. ve Demirel, F. (2008). Bilimsel Araştırma Yöntemleri. Ankara: Pegem Akademi.

Budak, G. ve Sürgevil, O. (2005). Tükenmişlik ve tükenmişliği etkileyen örgütsel faktörlerin analizine ilişkin akademik personel üzerinde bir uygulama. D.E.Ü.I.I.B.F. Dergisi, 20 (2), 95-108

Cevizci, A. (2010). Felsefeye Giriş. Ankara: Nobel Yayın Dağıtım. 
Chan, M. (2000). Organizational justice theories and landmark cases. The International Journal of Organizational Analysis, 8 (1), 68-88.

Cohen, L. Manion, L. \& Morrison, K. (2005). Research Methods in Education. London and New York: RoutledgeFalmer.

Cohen-Charash, Y. \& Spector, P. E. (2001). The role of justice in organizations: A meta-analysis. Organizational Behavior and Human Decision Processes, 86 (2), 278-321.

Colquit, J. A., Conlon, D. E., Wesson, M. J., Porter, C. O. L. H. \& Ng, K. Y. (2001). Justice at the millennium: A meta-analytic review of 25 years of organizational justice research. Journal of Applied Psychology, 86 (3), 425-445.

Çakır, T. (2009). Örgütsel iklim ve adaletin tükenmişlikle olan ilişkisi: Kadıköy İlçesi örneği. Yayımlanmamış yüksek lisans tezi. Yeditepe Üniversitesi Sosyal Bilimler Enstitüsü, İstanbul.

Çilenti, K. (1994). Ĕ̆itim Teknolojisi ve Öğretim. Ankara: Kadığlu Matbaas1.

Çokluk, Ö., Şekercioğlu, G. ve Büyüköztürk, Ş. (2010). Sosyal Bilimler İçin Çok Değişkenli İstatistik SPSS ve Lisrel Uygulamaları. Ankara: Pegem Akademi.

Ergin, C. (1992). Doktor ve hemşirelerde tükenmişlik ve Maslach Tükenmişlik Ölçeği’nin uyarlanması. VII. Ulusal Psikoloji Kongresi Bilimsel Çalışmaları, R. Bayraktar ve İ. Dağ (Editörler). Ankara: VII. Ulusal Psikoloji Kongresi Düzenleme Kurulu ve Türk Psikologlar Derneği Yayını, 143-154.

Erkanlı, H. (2009). Örgütsel adalet ve kültür ilişkisi: Türkiye'de faaliyet gösteren bazı işletmelerde karşılaştırmalı bir araştırma. Yayımlanmamış doktora tezi. Ankara Üniversitesi Sosyal Bilimler Enstitüsü, Ankara.

Folger, R. \& Cropanzano, R., (1998). Organizational Justice and Human Resource Management. California / London: SAGE Publications.

Girgin, G. (1995). İlkokul öğretmenlerinde meslekten tükenmişliğin gelişimini etkileyen değişkenlerin analizi ve bir model önerisi. Yayımlanmamış doktora tezi, Dokuz Eylül Üniversitesi Sosyal Bilimler Enstitüsü, İzmir.

Girgin, G. (2010). Öğretmenlerde tükenmişliğe etki eden faktörlerin araştırılması. Elektronik Sosyal Bilimler Dergisi, 9 (32), 32-48.

Greenberg, J. (1990). Organizational justice: Yesterday, today, and tomorrow. Journal of Management, 16 (2), 399-432.

Gürpınar, G. (2006). An empirical study of relationships among organizational justice, organizational commitment, leader-member exchange, and turnover intention. Yayımlanmamış yükssek lisans tezi, Yeditepe Üniversitesi Sosyal Bilimler Enstitüsü, İstanbul. 
Halbesleben, J. R. B. \& Buckley, M. R. (2004). Burnout in organizational life. Journal of Management, 30 (6), 859-879.

Irak, D. U. (2004). Örgütsel adalet: Ortaya çıkışı, kuramsal yaklaşımlar ve bugünkü durumu. Türk Psikoloji Yazıları, 7 (13), 25-43.

Izgar, H. (2003). Okul Yöneticilerinde Tükenmişlik. Ankara: Nobel Yayın Dağıtım.

Kalayc1, Ş. (Ed.). (2009). SPSS Uygulamalı Çok Değişkenli İstatistik Teknikleri. Ankara: Asil Yayın Dağıtım Ltd. Şti..

Kan, Ü. D. (2008). Bir grup okulöncesi öğretmeninde tükenmişlik durumunun incelenmesi. Kastamonu Ĕ̈itim Dergisi, 16 (2), 431-438.

Karaman, P. (2009). Örgütsel adalet algısı ile tükenmişlik arasındaki ilişkinin incelenmesine yönelik ögrretmenler üzerinde bir uygulama. Yayımlanmamış yüksek lisans tezi. Yıldız Teknik Üniversitesi Sosyal Bilimler Enstitüsü, İstanbul.

Kwak, A. (2006). The relationship of organizational injustice with employee burnout and counterproductive work behaviors: Equity sensitivity as a moderator. Doctoral dissertation, Central Michigan University. (UMI Number: 3204042)

Laçinoğlu, Z. (2010). İlköğretim okulu ögretmenlerinin örgütsel adalet algıları ile bazı örgütsel davranışlar arasındaki ilişki. Yayımlanmamış yüksek lisans tezi. Sakarya Üniversitesi Sosyal Bilimler Enstitüsü, Sakarya.

Lambert, E. G., Hogan, N. L., Jiang, S., Elechi, O. O., Benjamin, B. Morris, A., et al. (2010). The relationship among distributive and procedural justice and correctional life satisfaction, burnout, and turnover intent: An exploratory study. Journal of Criminal Justice, 38 7-16.

Liljegren, M. \& Ekberg, K. (2009). The associations between perceived distributive, procedural, and interactional organizational justice, selfrated health and burnout. Work: A Journal of Prevention, Assessment and Rehabilitation, 33, 43-51.

Maslach, C. \& Jackson, S. E. (1981). The measurement of experienced burnout. Journal of Occupational Behavior, 2, 99-113.

Maslach, C. \& Leiter, M. P. (2008). Early predictors of job burnout and engagement. Journal of Applied Psychology, 93 (3), 498-512.

Maslach, C., Schaufeli, W. B. \& Leiter, M. P. (2001). Job burnout. Annu. Rev. Psychol., 52, 397-422.

MEB (1999). Milli Ĕgitim Bakanlı̆̆ Illköğretim Müfettişleri Başkanlıkları Yönetmeliği. Tebliğler Dergisi, 2505.

MEB (2011). Milli Eğitim Bakanlığı Eğitim Müfettişleri Başkanlıkları Yönetmeliği. Resmi Gazete, 27974.

Meydan, C. H., Basım, H. N. ve Çetin, F. (2011). Örgütsel adalet algısı ve örgütsel bağlığın tükenmişlik üzerine etkisi: Türk kamu sektöründe bir araştırma. Bilig, 57, 175-200. 
Moorman, R. (1991). Relationship between organizational justice and organizational citizenship behaviors: Do fairness perceptions influence employee citizenship? Journal of Applied Psychology, 76 (6), 845-855.

Niehoff, B. P. \& Moorman, R. H. (1993). Justice as a mediator of the relationship between methods of monitoring and organizational citizenship behavior. Academy of Management Journal, 36 (3): $527-$ 556.

Nowakowski, J. M., \& Conlon, D. E. (2005). Organizational justice: Looking back, looking forward. International Journal of Conflict Management, 16 (1), 4-29.

Özmen, F. ve Şahin, Ş. (2010). İlköğretim müfettişlerinin soruşturma görevini yerine getirirken karş1laştıkları sorunlar. Dicle Üniversitesi Ziya Gökalp Ĕ̈itim Fakültesi Dergisi, 15, 92-109.

Peker, R. (2002). İlköğretim okullarında görev yapan öğretmenlerin mesleki tükenmişliklerine etki eden bazı faktörler. Uludağ Üniversitesi Eğitim Fakültesi Dergisi, 15 (1), 305-318.

Polat, S. (2007). Ortaögretim ögretmenlerinin örgütsel adalet algılarl, örgütsel güven düzeyleri ile örgütsel vatandaşlık davranışları arasındaki ilişki. Yayımlanmamış doktora tezi. Kocaeli Üniversitesi Sosyal Bilimler Enstitüsü, Kocaeli.

Polat, S. ve Celep, C. (2008). Ortaöğretim öğretmenlerini örgütsel adalet, örgütsel güven, örgütsel vatandaşlık davranışlarına ilişkin algıları. Kuram ve Uygulamada Eğitim Yönetimi, 54, 307-331.

Sağlam-Arı, G. ve Çına-Bal, E. (2008). Tükenmişlik kavramı: Birey ve örgütler açısından önemi. Yönetim ve Ekonomi, 15 (1), 131-147.

Schmiesing, R. J., Safrit, R. D. \& Gliem, J. A. (2003). Factors affecting OSU Extension Agents' perceptions of organizational justice and job satisfaction. Journal of International Agricultural and Extension Education, 10 (2), 25-33.

Söbü, A. (2005). Illkögretim müfettişlerinin sorunlart: IV. Hizmet bölgesi örneği. Yayımlanmamış yüksek lisans tezi. Cumhuriyet Üniversitesi Sosyal Bilimler Enstitüsü, Sivas.

Söyük, S. (2007). Örgütsel adaletin iş tatmini üzerine etkisi ve İstanbul ilindeki özel hastanelerde çalışan hemşirelere yönelik bir çalışma. Yayımlanmamış doktora tezi. İstanbul Üniversitesi Sosyal Bilimler Enstitüsü, İstanbul.

Töremen, F. ve Tan, Ç. (2010). Eğitim örgütlerinde adalet: Kavramsal bir çözümleme. Dicle Üniversitesi Ziya Gökalp Eğitim Fakültesi Dergisi, $14,58-70$.

Tümkaya, S. (2000). Akademik tükenmişlik ölçeğinin geliştirilmesi. Hacettepe Üniversitesi Eğitim Fakültesi Dergisi, 19, 128-133.

Uğurlu, C.T. (2009). İlköğretim okulu ögretmenlerinin örgütsel bă̆lllık düzeylerine yöneticilerinin etik liderlik ve örgütsel adalet 
davranışlarının etkisi. Yayımlanmamış doktora tezi. İnönü Üniversitesi Sosyal Bilimler Enstitüsü, Malatya.

Ünal, A. ve Kantar, Ş. (2011). İlköğretim denetçi yardımcılarının sorunları. Illkögretim Online, 10 (1), 180-196, [Online]: http://ilkogretimonline.org.tr

Yazıcıŏlu, Y. ve Erdoğan, S. (2004). SPSS Uygulamalı Bilimsel Araştırma Yöntemleri. Ankara: Detay Yayıncılık.

Yazıcıoğlu, İ. ve Topaloğlu, I. G. (2009). Örgütsel adalet ve bağl1lık ilişkisi. Konaklama işletmelerinde bir uygulama. İşletme Araştırmaları Dergisi, 1 (1), 3-16.

Yeniçeri, Ö., Demirel, Y. ve Seçkin, Z. (2009). Örgütsel adalet ile duygusal tükenmişlik arasındaki ilişki: İmalat sanayi çalışanları üzerine bir araştırma. KMÜ IIIBF Dergisi, 16, 83-99.

Yıldırım, F. (2002). Çalışma yaşamında örgütsel bağlllık ve örgütsel adalet ilişkisi. Yayımlanmamış doktora tezi, Ankara Üniversitesi Sosyal Bilimler Enstitüsü, Ankara.

Yıldırım, F. (2003). Çalışma yaşamında örgütsel bağlılık ile örgütsel adalet, örgüt temelli özsayg1 ve bazı kişisel ve örgütsel değişkenlerin ilişkisi. Mülkiye Dergisi, 27 (239), 371-402.

Yıldırım, F. (2007). İş doyumu ile örgütsel adalet ilişkisi. Ankara Üniversitesi SBF Dergisi, 62(1), 253-278.

Yıldırım, M. C. (2009). Yapılandırmacı ögrenme paradigması ilkeleri açısından ilkögretim okullarında öğretimsel denetim uygulamalarının değerlendirilmesi. Yayınlanmamış doktora tezi, İnönü Üniversitesi Sosyal Bilimler Enstitüsü, Malatya.

Yıldırım, M. C., Beycioğlu, K., Uğurlu, C. T. ve Sincar, M. (2011). Eğitim müfettişlerinin görev alanları boyutunda karşılaşılan sorunlar. III. Uluslararası Katılıml Eğitim Denetimi Kongresi Bildiriler Kitabı (s.483-497). Ankara: Sözkesen Matbaacıllk.

Y1lmaz, A. (2007). İlköğretim müfettişlerinin mesleki görevlerini yerine getirme durumlarl ile tükenmişlik düzeyleri arasındaki ilişki. Yayımlanmamış doktora tezi. Abant İzzet Baysal Üniversitesi Sosyal Bilimler Enstitüsü, Bolu. 
